\title{
Density of The Crested Black Macaque (Macaca nigra) and Habitat Quality in Tangkoko, Bitung, North Sulawesi
}

\author{
Edyson Maneasa*, Suddin Simandjuntak, Mokosuli Yermia Semuel \\ Program Studi Biologi Program Pascasarjana Universitas Negeri Manado, Tomohon, Indonesia.
}

\author{
Article History \\ Received : July $01^{\text {th }}, 2021$ \\ Revised : July $09^{\text {th }}, 2021$ \\ Accepted : July $15^{\text {th }}, 2021$ \\ Published : July $19^{\text {th }}, 2021$ \\ *Corresponding Author: \\ Edyson Maneasa \\ Program Studi Biologi \\ Program Pascasarjana \\ Universitas Negeri Manado, \\ Tomohon, Indonesia. \\ Email: emaneasa@gmail
}

\begin{abstract}
The Crested black macaque (Macaca nigra) is an endemic species to the Sulawesi Island, limited distribution, and Critically Endangered on the IUCN red list. The population density in the Tangkoko Conservation Forest Management Unit (CFMU) has decreased significantly due to habitat destruction and hunting. Existing data are based on the study in the northern part of Tangkoko. Currently, data from the southern is urgently needed so that population data covers the entire area, including to identify the habitat quality. The aims of this study was to (1) analyze the population density level of Crested black macaque at the Tangkoko CFMU, (2) identify the habitat characterize of Crested black macaque at the Tangkoko CFMU, (3) analyze the correlation between Crested black macaque density and habitat quality at the Tangkoko CFMU. The study was conducted from January to March 2020 in the sothern of Tangkoko CFMU, North Sulawesi. The data collection on the density of Crested black macaque is done by animals directly inventorying through surveys in the field. Observations are carried out by walking at speeds of $1-1.5 \mathrm{~km} / \mathrm{h}$ on each track and stopping at every $100 \mathrm{~m}$ to observe the surroundings. Data recorded is the number of individuals found using the line transect method. Vegetation data collection method used is habitat quality data collection carried out by making sample plots measuring $25 \mathrm{~m}$ x $25 \mathrm{~m}$ for tree level observations in lines with each distance between plots is $250 \mathrm{~m}$. Data recorded for dominance of vegetation are species names, number of individuals, and diameter at breast height of trees. The results showed that (1) the population density level of Crested black macaque was 15 individuals $/ \mathrm{km} 2$. The highest amount of density is found on the D4 was 72 individu/km2, the lowest on D1, D5, D6, and D7 with no macaques; (2) vegetation analyzed at 45 plots were important value index with the highest value of 86,95 is Ficus variegata on line D7 for tree level, and Theobroma cacao for pole level with highest value of 120,80 on line D4; (3) the correlation between density of Crested black macaque and habitat quality that shows a positive value based on the Pearson correlation test. Further research is needed to determine the relationship between population density, habitat disturbance, and hunting pressure.
\end{abstract}

Keywords: Crested black macaque, density, habitat, the Tangkoko Conservation Forest Management Unit

\section{Introduction}

The Crested black macaque (Macaca nigra) is a species of Macaca that is endemic to the Sulawesi Island, whose distribution is limited to the mainland of North Sulawesi, Lembeh Island, Manado Tua Island and Talise Island (Whitten et al 1987: Supriyatna and Wahyono, 2000). The conservation status of this monkey is critically endangered based on the IUCN red list (Lee et al, 2020). The level of animal endemicity in North Sulawesi is higher than other areas in Sulawesi. The Tangkoko Conservation Forest
Management Unit (CFMU) is one of the conservation areas in North Sulawesi and the only one in Bitung City. At the Tangkoko CFMU, the largest population of Crested black macaques was estimated to be 1,951 individuals (Palacios, 2011).

The disturbance of the forest habitat can cause disruption to the wildlife, especially fruiteating primates. The largest proportion of Crested black macaque feed is fruit, but based on the composition of the feed this animal is omnivorous which also consumes leaves, flowers, seeds, tubers, as well as insects, 
mollusks and invertebrates (O'Brien and Kinnaird, 1997). The Crested black macaque population is strongly influenced by habitat changes in the Tangkoko CFMU because the largest habitat and population in North Sulawesi is only in this area. The density in the Tangkoko CFMU decrease $78.48 \%$, from the data comparison of the studied in 2010 and 2017 from 44.9 individuals $/ \mathrm{km}^{2}$ (Palacios, 20011) to 9.66 individuals $/ \mathrm{km}^{2}$ (Febriyanti et al., 2019), data collection was focused to the northern side of the area, it is recommended to conduct a density study of the Crested black macaque in the southern part of the Tangkoko CFMU so that the data obtained is more comprehensive. Data of the Crested black macaque on the density level and the quality of the habitat in the entire area are needed to develop a better conservation strategy for this critically endangered species.

Research conducted in the southern part of the Tangkoko CFMU to analyze the density level of Macaca nigra in the southern part of the Tangkoko CFMU. We did characterize the habitat which include composition, and vegetation structure in the southern of the reserve. We also analyzed the relationship between habitat quality and population density of the Crested black macaque.

\section{Materials and Methods}

\section{Study site}

The study was conducted in January to March 2020 in the southern part of the Tangkoko Conservation Forest Management Unit CFMU), that geographically located at $1^{\circ} 31.325^{\prime}$ $1^{\circ} 27.782^{\prime} \mathrm{N}$ and $125^{\circ} 8.192-125^{\circ} 14.898 \mathrm{E}$, and included in Bitung City, North Sulawesi Province, Indonesia.

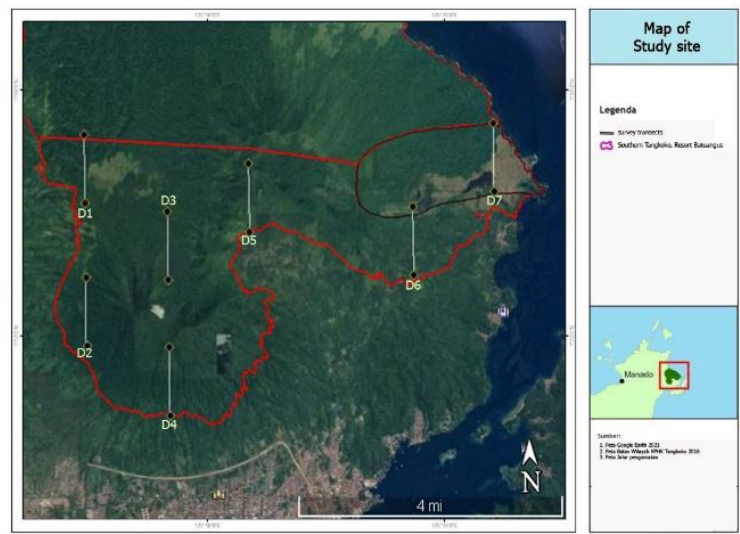

Figure 1. Research location

\section{Materials and Tools}

The research material is the Crested black macaque (Macaca nigra) and habitat components in the southern part of the Tangkoko CFMU. The equipment used are binoculars, GPS, range finder, compass, meter, rope, tally sheet, the Tangkoko CFMU maps and computers.

\section{Data Collection}

Data collection was carried out on seven lines transect survey (Buckland et al., 2015) that were made systematically throughout the observation area (Figure 1), covering various types of habitats at an altitude of $0-1000 \mathrm{~m}$ asl. The length and width of the path are varied between 1000 to $1500 \mathrm{~m}$, adjusted to the topography conditions and area boundaries.

Vegetation data collection using the plotted path method. Sampling plots with a size of $25 \times 25 \mathrm{~m}$ to collect data at the pole and tree level. 45 plots were made in each observation path with a distance between plots of $250 \mathrm{~m}$. Data collected for composition and dominance were species name, diameter at breast height and number of individuals.

Macaca nigra data collection by walking on line transect at a speed of 1 to $1.5 \mathrm{~km} / \mathrm{hour}$. Observers will stop every $100 \mathrm{~m}$ to observe the surroundings and hear the presence of animals. Observation time is in the morning between 06.00 to 11.00 and in the afternoon from 14.00 to 17.00. The data recorded is the number of individuals or groups of monkeys, and the perpendicular distance from the line transect.

\section{Data analysis}

The density of individual monkeys can be done by analyzing the number of individual encounters in a group of animals during the observation. According to the National Research Council (1981), the individual density of the Crested black macaque was calculated using the equation:

$$
D=\frac{n}{2 w L}
$$

Where: $\mathrm{D}=$ density, $\mathrm{n}=$ number of individuals/groups sighted, $\mathrm{w}=$ width of one side of transect $(\mathrm{km})$, and $\mathrm{L}=$ transect length $(\mathrm{km})$.

The quantitative parameter used is the Important Value Index (INP) to express the level of dominance (mastery) of species in the tree community. Some equations for calculating INP (Mueller-Dombois and Ellenbergh, 2016): Density (ind/ha) $=$ Number of individuals of species (ind) 
Total area of sample plots (ha)

Relative Density (KR) (\%) = Density of a species x 100\% Density of all species

Dominance $\left(\mathrm{m}^{2} / \mathrm{ha}\right)=$ Number of basal area $\left(\mathrm{m}^{2}\right)$ Total plots area (ha)

Relative Dom. $/$ DR $(\%)=$ Dominance of a species x $100 \%$ Dominate all species

Frequency $=\underline{\text { Total number of plots species presented }}$ Total number of plots studied Relative Freq. $(\mathrm{FR})(\%)=$ Frequency of a species $\mathrm{x} 100 \%$ Frequency of all species

Important Value Index $(\mathrm{INP})=\mathrm{KR}+\mathrm{DR}+\mathrm{FR}$

Basal area of a species $=1 / 4 \pi \mathrm{d}^{2}$

The relationship between Macaca nigra density and habitat quality in the southern part of the Tangkoko CFMU was determined by the Pearson Correlation test.

\section{Results and Discussion}

\section{Macaque Density}

The Crested black macaques in the wild usually live in large groups with the number of individuals ranging from 20 to 70 individuals (Supriatna and Wahyono, 2000). The density in seven line transect with the total survey effort of $67.55 \mathrm{~km}$, resulted from 49 days of effective surveying, the density of Crested black macaque in Tangkoko was $15(0-72)$ individuals $/ \mathrm{km}^{2}$ (Table 1).

Table 1. Density of Crested black macaque in Tangkoko.

\begin{tabular}{ccc}
\hline Transect & $\begin{array}{c}\text { Length of } \\
\text { transect }(\mathbf{k m})\end{array}$ & $\begin{array}{c}\text { Density } \\
\text { (invidu/ } \mathbf{k m}^{\mathbf{2}} \text { ) }\end{array}$ \\
\hline D1 & 1,50 & 0 \\
D2 & 1,50 & 15 \\
D3 & 1,50 & 15 \\
D4 & 1,50 & 72 \\
D5 & 0,75 & 0 \\
D6 & 1,40 & 0 \\
D7 & 1,50 & 0 \\
\hline Average & $\mathbf{1 5}$ \\
\hline Total & $\mathbf{6 7 , 5 5}$ \\
\hline Note: D1,...,D7 = Duasudara1,..,Duasudara7
\end{tabular}

The highest density of Crested black macaques was found in lane D4. The location of the lane D4 is at the foot of Duasudara mountain where borders with the community plantation, and even some plantation crops are planted in the Duasudara Nature Reserve. The probability to records the monkeys is high. According to Lengkong (2011), Crested black macaques often visit plantations and eat the plants which planted by the community, so the monkeys are considered as well as pests to the crops.

The lowest or no encounters with Crested black macaques in four observation lines are D1, D5, D6 and D7. The location of the D1 has a habitat type of shrubs and weeds so it is not possible for animals to be able to use it as a shelter from predators, for feeding, and other daily activities. While on the observation lines D5, D6, and D7 with habitat types of the secondary and primary forests, the high activity of human caused the Crested black macaque to avoid.

The density of Crested black macaques in the southern Tangkoko was $35.6 \%$ greater than the study in the northern Tangkoko in 2017 (Febriyanti et al., 2019) which used the same line transect method, the density is 9.66 individuals $/ \mathrm{km} 2$. Differences in density can be influenced by the total length of the transect, $122.50 \mathrm{~km}$ (in 11 lines) compared to $67.55 \mathrm{~km}$ (in seven lines), the number of repetitions, the time of the study, the ability to detect animals and differences in habitat conditions between the northern and southern parts of the Tangkoko CFMU.

\section{Habitat characteristics}

Vegetation analysis of 45 tree observation plots on the study area, the results were 112 trees from 42 species at the poles level and 427 trees from 72 species at the tree level. The dominant species with the highest IVI is Theobroma cacao at the poles level, and trees is Ficus variegata (Table 2.)

Table 2 shows the highest INP value at the poles level in all transect is Theobroma cacao of 120.80 on D4. Theobroma cacao or cacao is a plant cultivated by the community, although the status of the area is a Nature Reserve which does not allow any human activities include agricultural, but community crops have penetrated into the Duasudara forest. This is in accordance with the statement of Lengkong (2011), that the surrounding community's crops has penetrated into the nature reserve area to be planted with crops including cocoa.

The highest INP at the trees level is Ficus variegata with a value of 86.95 on the D7 transect. According to Pamekas et al (2015), Ficus variegata is the top third favorite forage tree for Crested black macaques from 22 species of foraging tree recorded. This indicates that sufficient forage trees are available in the research path. 
Table 2. The highest Importance Value Index (IVI) at the poles and trees level in each line transect

\begin{tabular}{clllllll}
\hline Line & Level & \multicolumn{1}{c}{ Species } & Family & KR(\%) & FR(\%) & DR(\%) & INP \\
\hline \multirow{2}{*}{ D1 } & Poles & Polyalthia sp. & Annonaceae & 40,00 & 40,00 & 35,90 & 115,90 \\
& Trees & Spathodea campanulata & Bignoniaceae & 34,38 & 6,06 & 36,30 & 76,74 \\
& Poles & Trema orientalis & Cannabaceae & 26,32 & 12,50 & 15,62 & 54,43 \\
D2 & Trees & Aglaia sp. & Meliaceae & 15,38 & 7,14 & 16,20 & 38,72 \\
& Poles & Ficus ampelas & Moraceae & 16,67 & 17,65 & 27,51 & 61,82 \\
D3 & Trees & Canarium sp. & Burseraceae & 2,92 & 37,80 & 4,03 & 44,75 \\
& Poles & Theobroma cacao & Malvaceae & 47,37 & 25,00 & 48,43 & 120,80 \\
D4 & Trees & Homalium celebicum & Flacourtiaceae & 5,00 & 3,23 & 50,98 & 59,21 \\
& Poles & Aglaia sp. & Meliaceae & 25,00 & 16,67 & 24,23 & 65,89 \\
D5 & Trees & Syzygium aromaticum & Myrtaceae & 15,79 & 15,38 & 15,07 & 46,24 \\
& Poles & Gliricidia sepium & Fabaceae & 30,00 & 22,22 & 36,98 & 89,20 \\
& Trees & Ficus sp. & Moraceae & 6,67 & 9,09 & 64,70 & 80,46 \\
& Poles & Ficus variegata & Moraceae & 23,08 & 11,76 & 35,25 & 70,09 \\
& Trees & Ficus variegata & Moraceae & 35,00 & 13,79 & 38,16 & 86,95 \\
\hline
\end{tabular}

Note: $\mathrm{KR}=$ relative density, $\mathrm{FR}=$ relative density, $\mathrm{DR}=$ relative dominance, $\mathrm{INP}=$ important value index

\section{Relationship of macaque Density and Habitat Quality}

The life of wild animal is very dependent on the quality of the forest as a habitat to find the food and sleeping tree. The relationship between population density and quality parameters can be seen in Table 3.

Table 3. Relationship between Crested black macaque density and habitat quality.

\begin{tabular}{|c|c|c|c|}
\hline $\begin{array}{l}\text { Population } \\
\text { parameter }\end{array}$ & $\begin{array}{l}\text { Habitat } \\
\text { quality } \\
\text { parameter }\end{array}$ & Correlation & $\begin{array}{l}\text { Direction } \\
\quad \text { and } \\
\text { strength of } \\
\text { correlation }\end{array}$ \\
\hline \multirow{2}{*}{$\begin{array}{l}\text { Density of } \\
\text { Crested } \\
\text { black } \\
\text { macaque }\end{array}$} & Poles INP & 0,479 & $\begin{array}{l}\text { Moderately } \\
\text { positive }\end{array}$ \\
\hline & Trees INP & $-0,259$ & $\begin{array}{c}\text { Weakly } \\
\text { negative }\end{array}$ \\
\hline
\end{tabular}

The parameters analyzed were the density of the Crested black macaque and the Importance Value Index for habitat quality had a positive relationship with a weak correlation level for the poles level, but the macaque density and tree INP had a negative relationship with a weak correlation. These results indicate that the population density of the Crested black macaque is not strongly influenced by tree dominance, but other habitat quality factors might be more influential. As seen in transects D2, D3 and D4 which have a high density of Crested black macaques with a high diversity index in the same transects. This shows that the Crested black macaques tend to prefer a more diverse habitat to meet their needs for food, rest, and sleep, which is supported by the results of research by O'Brien and Kinnaird (1997) that the diversity of feed for Crested black macaques in Tangkoko reaches 145 fruit tree species.

\section{Conclusions}

The density of Crested black macaque ( $M$. nigra) at the study site is 15 individuals $/ \mathrm{km} 2$, with the highest density on transect D4 72 individuals $/ \mathrm{km} 2$, the lowest density without recorded is on transects D1, D5, D6, and D7. Analysis of the highest INP is Ficus variegata with 86.95 value. The availability of forage trees in all line transect was an average of $48.00 \%$ with the highest presence in D7 and the lowest in D5. The relationship between Crested black macaque density and habitat quality showed a positive correlation on poles level and weakly negative correlation on trees level.

\section{Acknowledgements}

We gratefully acknowledge the permission of the North Sulawesi BKSDA, the Tangkoko CFMU and Macaca Nigra Project for the data collection. And thanks also to EPASS Tangkoko project for highly support.

\section{References}

Alikodra, H.S. (2010). Teknik Pengelolaan Satwa Liar dalam Rangka Mempertahankan Keanekaragaman Hayati Indonesia. IPB Press. Bogor. ISBN: 978-979-493-192-9, pp: 368.

Buckland, S.T., Rexstad, E.A., Marques, TA., \& Oedekoven. C.S. (2015). Distance 
Sampling: Methods and Applications. Methods in Statistical Ecology. Springer International Publ ishing. AG Switzerland. DOI 10.1007/978-3-319-19219-2, pp: 277.

Febriyanti, D.Y., Kiroh, H.J., \& Saroyo. (2019). Kajian Kualitas Habitat dan Tingkat Kepadatan Monyet Hitam Sulawesi (Macaca nigra) di Kesatuan Pengelolaan Hutan Konservasi (KPHK) Tangkoko Sulawesi Utara. Agri-SosioEkonomi Unsrat, 15(1): 65 - 70. DOI: http://ejournal.unsrat.ac.id/index.php/jisep /article/view/23366/23058.

Katili, D. \& Saroyo, (2011). Perbandingan Aktivitas Harian Dua Kelompok Monyet Hitam Sulawesi (Macaca Nigra) Di Cagar Alam Tangkoko-Batuangus, Sulawesi Utara. Jurnal Ilmu Sains, 11 (2): 161-165. DOI:10.35799/jis.11.2.2011.201

Kyes, R.L., Iskandar, E., Onibala, J., Paputungan, U., Laatung, S., \& Huettmann, F. (2012). Long-term Population Survey of the Sulawesi Black Macaques (Macaca nigra) at Tangkoko Nature Reserve, North Sulawesi, Indonesia. American Journal of Primatology, $\quad 75(1), \quad 81-88 . \quad$ DOI: 10.1002/ajp.22088

Laatung, S. (2015). Stratifikasi Penggunaan Tajuk oleh Yaki (Macaca nigra) di Cagar Alam Tangkoko Duasudara Sulawesi Utara. Jurnal Zootek 35(1): 151-163. DOI: https://doi.org/10.35792/zot.35.1.20 15.7224

Lee, R., Riley, E., Sangermano, F., Cannon, C. \& Shekelle, M. (2020). Macaca nigra. The IUCN Red List of Threatened Species 2020: e.T12556A17950422. https://dx.doi.org/1 0.2305/IUCN.UK.2020-

3.RLTS.T12556A17950422.en. (Accesse d on July 15, 2021)

Lengkong, H.J. (2011). Laju Degradasi Habitat Monyet Hitam Sulawesi (Macaca nigra) di Cagar Alam Gunung Duasudara Sulawesi Utara. Jurnal Ilmiah Sains, 11(1): $\quad 31-35 . \quad$ DOI:
https:/.ejournal.unsrat.ac.id/index.php/JIS /article/view/37

Melfi, V., (2010). Selamatkan Yaki! Conservation of Sulawesi Crested Black Macaques Macaca nigra, Gursky-Doyen, S. and J. Supriatna (Eds.) Indonesian Primates. Springer. New York. 343-358. DOI: 10.1007/978-1-4419-1560-3

Mueller - Dombois, D., \& Ellenbergh, H. (2016). Aims and Methods of Vegetation Ecology. Terjemahan K. Kartawinata dan R. Abdulhadi. LIPI Press. Jakarta. ISBN: 978-979-799-852-3, pp: 610

National Research Council. (1981). Techniques for the Study of Primate Population Ecology. The National Academy Press. Washington, DC. DOI: 10.17226/18646, pp: 255

O’Brien T.G. \& Kinnaird, M.F. (1997). Behaviour, Diet, and Movement of the Sulawesi Crested Black Macaque (Macaca nigra). International Journal of Primatology 18(3): 321-351. DOI: 10.1023/A: 1026330332061

Palacios J.F.G, A. Engelhardt, M. Agil, K. Hodges, R. Bogia \& Waltert, M. (2011). Status of and Conservation Recommendation for, the Critically Endangered Crested Black Macaque Macaca nigra in Tangkoko, Indonesia. Fauna and Flora International, Oryx, 46(2): 290-297. DOI: https://doi.org/10.1017/ S0030605311000160

Pamekas, Tasirin J.S., Kainde R.P. \& Sumakud, M.Y.M.A. (2015). Inventarisasi Jenis Tumbuhan Pakan Monyet Hitam Sulawesi (Macaca nigra) di Taman Wisata Alam Batuputih Sulawesi Utara. Cocos 6(10): 17.

DOI: https:/.ejournal.unsrat.ac.id/index.php/coc os/article/view/8386.

Rossenbaum B., T.G O’Brien, M.F. Kinnaird \& Supriyatna, J. (1998). Population Densities of Sulawesi Crested black macaque (Macaca nigra) on Bacan and Sulawesi, Indonesia: Effect of Habitat Disturbance and Hunting. American Journal of 
Primatology, 44: 89-106. DOI: 10.1002/(SICI)1098-2345(1998)44: 2<89: AID-AJP1>3.0.CO;2-S

Rowe N. (1996). Pictorial Guide to the Living Primates. Pogonias Press. Charlestown. ISBN: 0-9648825-0-7, pp: 263.

Saroyo, Mansjoer S.S., Tarumingkeng, R.C., Solihin, D.D., \& Watanabe, K. (2006). Aktifitas Harian Monyet Hitam Sulawesi (Macaca nigra) di Cagar Alam TangkokoBatuangus, Sulawesi Utara. Biosfera, 23(1): $\quad$ 44-49. https://repository.ipb.ac.id/bitstream/hand le/123456789/58852/biosfera1b.pdf;jsessi onid=7A027C7ECDE253DD55E1174BA 3EB5CED? sequence $=1$

Saroyo \& Koneri, R. (2010). Pemetaan Distribusi dan Densitas Monyet Hitam Sulawesi (Macaca nigra) di Sulawesi Utara. Biosfera, $27(3): \quad 133 \quad$ - 139. DOI: 10.20884/1.mib.2010.27.3.203

Supriatna, J. \& Wahyono, E.H. (2000). Panduan Lapangan Primata Indonesia. Yayasan Obor Indonesia. Jakarta. ISBN: 979-461355-X, pp: 334.

Whitten, T.G, Henderson S, \& M. Mustafa (1987). The Ecology of Sulawesi. Terjemahan G. Tjitrosoepomo. Gadjah Mada University Press. Yogyakarta. ISBN: 940-420-055-7, pp: 844. 